Per Schubert is a Ph.D. in physical geography and a lecturer in physical geography with focus on didactics. For example, he is teaching geography, natural science, environmental science, sustainable development, and didactics within the teacher education and has recently been working within a research project on the implementation of ecosystem services in municipal planning.

Maria Johansson is a licentiate in educational sciences and a Ph.D. student in pedagogy. She has extensive experience of upper-secondary school teaching and teacher training and is currently teaching pedagogy within the teacher education. Her research is currently focused on validation, also labelled as recognition or accreditation of prior learning, with a particular interest in vocational knowledge.

\title{
PER SCHUBERT
}

Department of Natural Science, Mathematics and Society, Malmö University, Sweden

per.schubert@mau.se

\section{MARIA JOHANSSON}

Department of Education and Teachers' Practice, Linnaeus University, Sweden

maria.c.johansson@Inu.se

\section{Geografiska informationssystem som en integrerad del av lärarutbildningen och skolundervisningen}

\begin{abstract}
The Swedish school education in geography has developed slowly and still focuses on names of, for example, countries and capitals, rather than geographical concepts and processes. To implement the secondary and upper secondary school curricula, teachers need both broad and deep geographical knowledge. For example, teachers need knowledge of geographic information systems (GIS), which are computerised information systems for analysis and presentation of geographical data. This literaturebased discussion article aims to analyse opportunities and difficulties with using GIS programs in the teacher and school education. In summary, the preconditions are good, with few technical barriers, for developing GIS-based teaching in the teacher and school education that promotes active, inquiry-based, cooperative, and problem-based learning. This would make the school education more problemoriented and interdisciplinary so that it promotes pupils' opportunities to achieve the competencies stipulated in the curricula. Such development requires that teacher educators and school teachers get the time and resources needed to develop technological pedagogical content knowledge. However, it is probably enough for educators and teachers to get started with simpler internet- and web-based GIS and then develop their knowledge at an appropriate pace.
\end{abstract}

\section{INLEDNING}

Skolans geografiundervisning har utvecklats alltför långsamt, och studier visar på att undervisningen fortfarande domineras av namngeografi där elever får lära sig namn på exempelvis länder och huvudstäder istället för geografiska begrepp och processer (Molin, 2006; Molin \& Örbring, 2017). 
Enligt kursplanen för ämnet geografi i grundskolan omfattar geografi förutsättningarna för liv på jorden, samspelet mellan människan och hennes omgivning och hur människan bör förvalta sina livsmiljöer på ett hållbart sätt (Skolverket, u.å.a). Av det centrala innehållet framgår att skollärare inte endast behöver ha breda natur- och kulturgeografiska kunskaper, utan också fördjupade kunskaper om specifika delar av geografin. Då geografi är tvärvetenskapligt ställer detta höga krav även på att lärare behärskar många olika undervisningsformer såsom föreläsningar, seminarier, grupparbeten, övningar, laborationer, datorlaborationer och exkursioner. Lärarutbildningen måste göra sitt bästa för att leva upp till dessa höga kunskapskrav så att våra blivande geografilärare får möjligheten att utöva yrket både enligt läroplanen och tillämplig pedagogik. Breda och djupa kunskaper möjliggör för lärare att stärka elevers eget lärande, inte bara genom att entusiasmera elever och därigenom öka deras egen motivation (McKeachie \& Svinicki, 2006), utan också genom att uppmuntra till diskussioner med ett starkare fokus på förståelse, argumentation, begreppsbildning och kritiskt tänkande, i stället för utantillkunskap (Biggs \& Collis, 1982; Biggs \& Tang, 2007; Marton \& Säljö, 1976; Ramsden, 1992). Observera följande centrala innehåll i kursplanen för geografi i årskurserna 7-9 som är av speciellt intresse för denna diskussionsartikel:

Metoder för att samla in, bearbeta, värdera och presentera geografiska data, till exempel om klimat, hälsa och handel, med hjälp av kartor, geografiska informationssystem (GIS) och geografiska verktyg som finns tillgängliga på Internet, till exempel satellitbilder.

Skolverket (u.å.a)

Lärare behöver alltså fördjupade kunskaper om geografiska informationssystem (GIS) som är datoriserade informationssystem för insamling, lagring, hantering, bearbetning, analys och presentation av geografiska data (Harrie, 2013). Exempel på enkla former av geografisk informationsbehandling är att visualisera rumsliga och temporala förhållanden med hjälp av kartor, tabeller och grafer. Mer avancerade exempel är att göra urval, söka, lokalisera och analysera rumsliga förhållanden och flöden samt att studera rumsliga och temporala förändringsprocesser. GIS används och har stor betydelse för många verksamheter såsom samhällsplanering, miljöövervakning, räddningsverksamhet, byggnation, förvaltning och forskning. Allmänt kända och använda GIS-program och -tillämpningar är olika karttjänster på internet.

Ämnesplanen för geografi i gymnasiet täcker in kursplanen för årskurserna 7-9 och utvecklar innehållet med ytterligare kunskaper. Observera exempelvis vad som står i ämnesplanen för geografi i gymnasiet:

Eleverna ska även ges möjlighet att utveckla kunskaper om samhällets behov av olika rumsliga data samt om hur stora informationsmängder kan hanteras med hjälp av digitala geografiska verktyg som geografiska informationssystem (GIS).

Färdigheter $i$ att använda digitala geografiska verktyg för att analysera och visualisera rumsliga förhållanden.

Skolverket (u.å.b)

I gymnasieskolans tre kursplaner är kunskaper i GIS ännu tydligare framskrivna där den tredje särskilda programkursen i GIS helt och hållet fokuserar på GIS, datakällor, analys och samhällets behov av geografisk information. Vi har alltså en tydlig progression av GIS-kunskaper från grundskolan till gymnasiet där elevers användning av GIS făr en mer framträdande roll.

Skolverket (2016a) påpekar att endast cirka femton svenska gymnasieskolor har genomfört den särskilda programkursen i GIS. En av svårigheterna med att utveckla skolans GIS-undervisning är att lärare inte gärna använder verktyg som de inte har utbildats för (Kerski, 2003; Wechsler \& Pitts, 2004). Lärare som har studerat före införandet av de nya läro-, ämnes- och kursplanerna för 
grund- och gymnasieskolan saknar ofta tillräckliga GIS-kunskaper. Detta har framgått med tydlighet när vi har besökt våra lärarstudenter under deras verksamhetsförlagda utbildning (VFU) och när vi har diskuterat med studenterna om deras erfarenheter från sina VFU-skolor. Det blev även tydligt under den introduktion till GIS som jag (Per) höll för lärare och andra intresserade i regi av Geografilärarnas Riksförening. Intresset var stort men flera lärare nämnde att skolorna inte betalar för deras fortbildning och att de har svårigheter med att tillägna sig GIS-kunskaper på egen hand. Lärares kunskaper släpar efter inte bara här i Sverige utan även i andra länder som exempelvis Finland, Norge, Singapore, Turkiet, Tyskland och USA (Andersland, 2011; Baker \& Bednarz, 2003; Demirci, 2009; Hauselt \& Helzer, 2012; Johansson, 2012; Schubert \& Uphues, 2009; Yong Yap, Tan, Zhu, \& Wettasinghe, 2008). Med andra ord är det dags att ge dagens lärarstudenter möjligheten att tillägna sig denna kunskap, så att de har den med sig ut i skolorna när de är färdiga med sin utbildning.

Mot bakgrund av GIS-innehållet i skolans styrdokument (Skolverket, 2016b) och lärarnas uttryckta behov av mer GIS-kunskaper är syftet med denna litteraturbaserade diskussionsartikel att analysera möjligheter och svårigheter med användning av GIS i lärarutbildningen och skolundervisningen. Kommande avsnitt tillhandahåller bland annat korta referat av vetenskapliga studier om GIS i lärarutbildningen och skolundervisningen för att bidra med information om hur man har genomfört studierna och kommit fram till sina resultat. På detta sätt sammanfattar vi möjligheter och svårigheter för att sedan diskutera dessa. Även om denna text är skriven i en svensk kontext går den säkert att relatera till andra länders förhållanden. Texten riktar sig till lärare och administratörer på universitet, högskolor och skolor och är avsedd som ett underlag för att diskutera och vidareutveckla utbildningen av geografilärare för årskurserna 7-9 och gymnasiet.

\section{TEORETISK BAKGRUND}

John Deweys aktivitetspedagogik, Lev Vygotskijs socio-kulturella teori och Piagets konstruktivistiska teori har haft stor betydelse för den pedagogiska teori- och begreppsutvecklingen samt utvecklingen undervisningsformerna aktivt, kooperativt, forskningsbaserat och problembaserat lärande. Dessa och andra undervisningsformer främjar utvecklingen av de fyra kunskapsformer och de förmågor som tillsammans utgör styrdokumentens sammansatta kunskapsbegrepp. De fyra kunskapsformerna fakta, förståelse, förtrogenhet och färdighet bör betraktas utan inbördes rangordning och bildar tillsammans grunden för utvecklingen av de förmågor som undervisningen och elever strävar efter att uppnå (Carlgren, 2011). De fem vanligaste och mest centrala förmågorna har fått benämningen The Big 5: begreppsförmåga, analysförmåga, metakognitiv förmåga, procedurförmåga och kommunikativ förmåga (Svanelid, 2014). I kursplanen för årskurserna 7-9 respektive ämnesplanen för gymnasiet kan vi läsa följande:

...göra geografiska analyser av omvärlden och värdera resultaten med hjälp av kartor och andra geografiska källor, teorier, metoder och tekniker...

Skolverket (u.å.a)

Förmåga att använda olika geografiska källor, metoder och tekniker vid arbetet med geografisk analys samt att samla in, bearbeta, värdera och presentera geografisk information.

Skolverket (u.å.b)

Vi får anta att även andra förmågor förutsätts i dessa citat, även om endast analysförmåga är explicit uttryckt. Mot bakgrund av de förmågor som styrdokumenten föreskriver är det anmärkningsvärt att utvecklingen av skolans geografiundervisning har fastnat i ett fokus på namngeografi (Molin, 2006; Molin \& Örbring, 2017). Här kommer GIS in som ett utmärkt exempel på informations- och kommunikationsteknologi (IKT) som möjliggör undervisning om komplexa ämnesövergripande problem- 
områden och på detta sätt ökar elevers möjligheter att uppnå styrdokumentens förmågor. Detta ställer dock krav på att lärare har teknologisk pedagogisk ämneskunskap som är en kombination av teknologisk kunskap och pedagogisk ämneskunskap (Mishra \& Koehler, 2006). Begreppet pedagogisk ämneskunskap introducerades av Shulman (1986) och kan placeras i gränslandet mellan ämneskunskap och pedagogisk kunskap. Pedagogisk ämneskunskap är den speciella ämneskunskap som lärare behöver för att kunna undervisa i ämnet och inkluderar de mest användbara representationsformerna av något ämnesinnehåll, såsom exempel, analogier, förklaringar, illustrationer och demonstrationer. Sådan kunskap inkluderar även förståelse av vad det är som gör ett visst ämnesinnehåll lätt eller svårt att lära sig, så att man som lärare har förmågan att använda lämpliga representationsformer i olika lärandesituationer.

\section{LITTERATURSÖKNING}

Styrdokumenten för grund- och gymnasieskolan finns tillgängliga för nedladdning via Skolverkets hemsida (https://www.skolverket.se). Databaserna Education Research Complete (ERC), Education Resources Information Center (ERIC), Google Scholar samt Journal STORage (JSTOR) användes för att hitta peer review-granskade forskningsartiklar med fokus på möjligheter och svårigheter med användning av GIS i lärarutbildningen och skolundervisningen. Det är ovanligt med svenska vetenskapliga publikationer inom området (Molin \& Örbring, 2017), och därför kombinerades följande engelska primära söktermer: geographical information system, geography, higher education, K12, school, school teacher, teacher education och university. Sökningar med geographical information system i kombination med någon av de övriga söktermerna gav flest och mest relevanta träffar. Sökningarna var breda och artiklarnas sammanfattningar låg till grund för urvalet av artiklar. Utöver detta bidrog artiklarnas litteraturlistor med ytterligare referenser. Det slutliga urvalet består av senare artiklar som går att relatera till svenska förhållanden, dels för att GIS har utvecklats snabbt över tid, dels för att vårt syfte handlar om GIS i den nuvarande undervisningen som utgår från läroplanerna från 2011.

\section{MÖJLIGHETER OCH SVÅRIGHETER MED GIS I LÄRARUTBILDNINGEN OCH SKOLUNDER- VISNINGEN}

Baserat vald litteratur, olika hemsidor och samlad erfarenhet av GIS i lärarutbildningen och skolundervisningen fokuserar vi på följande teman:

- Tekniska möjligheter och svårigheter

- Möjligheter och svårigheter i lärarutbildningen

- Möjligheter och svårigheter i skolundervisningen.

\section{Tekniska möjligheter och svårigheter}

Tidigare har de största hindren för implementering av GIS i skolan i olika delar av världen varit tillgången på datorer och programvaror (Lam, Lai, \& Wong, 2009). Dagens svenska universitet/högskolor och skolor tillhandahåller datorer, så detta ska inte längre vara något större hinder. Numera finns det också en hel del gratis tillgängliga internet-, webb- och desktopbaserade programvaror på internet. En lista med sådana programvaror finns på informationsportalen GIS Lounge (http://www. gislounge.org). Tre programvaror som kan vara lämpliga för årskurserna 7-9 respektive gymnasiet är det internetbaserade Google Earth, det webbaserade National Geographics MapMaker Interactive (https://mapmaker.nationalgeographic.org) och det desktopbaserade QGIS, där den senare är ett så kallat äkta GIS som används professionellt av företag, organisationer och myndigheter. Figur 1 visar ett exempel på hur man genom att läsa in så kallade KML- eller KMZ-filer kan visa grafik ovanpå satellitbilderna i Google Earth (cf. Paterson, 2007; Ratinen \& Keinonen, 2011). Den valda grafiken illustrerar bland annat tektoniska plattors gränser och rörelser som kan användas för att förklara förekomster av exempelvis bergskedjor, djuphavsgravar, jordbävningar och vulkaner. 


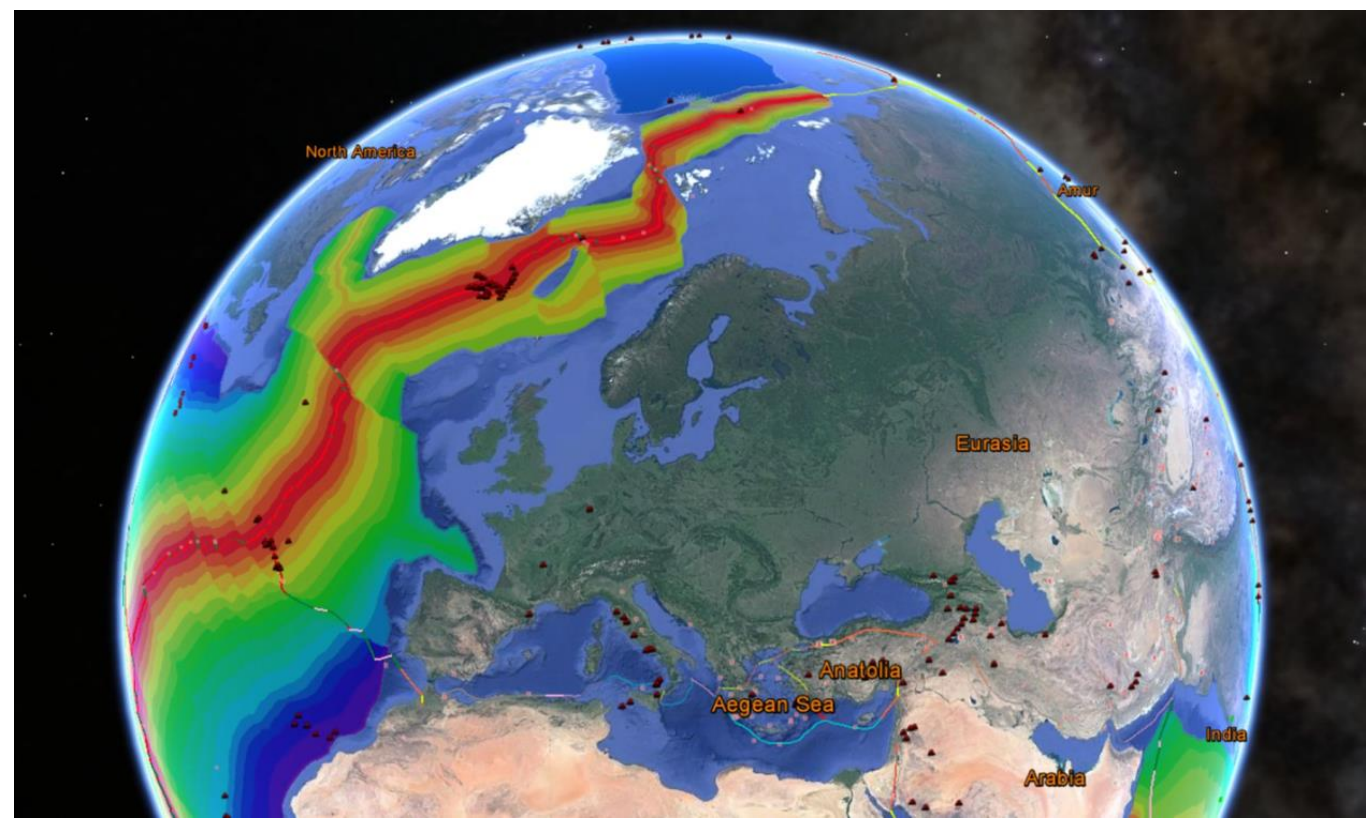

Figur 1. Grafik ovanpå satellitbilder i Google Earth som illustrerar tektoniska plattors gränser och rörelser. Källor: Google Earth (2016) och Goodell (2016).

Förmodligen är det lämpligt att reservera QGIS för gymnasiet. Digitala kartdata, flygbilder och satellitdata finns också tillgängliga på internet för gratis nedladdning. En lista med sådana data finns på informationsportalen GISGeography (https://gisgeography.com/). Till exempel tillhandahåller QGIS ett tillhörande paket med data och andra användbara datakällor är Natural Earth och OpenStreetMap. Dock är det önskvärt att universitet/högskolor och skolor har tillgång till Lantmäteriets dataproduktion, dels för att kvaliteten är hög, dels för att det blir mycket enklare att utveckla undervisningsmaterial med tillämpningar på svenska geografiska förhållanden. Det är fullt möjligt för universitet/ högskolor och skolor att få tillgång även till Lantmäteriets data, genom Geodatastrategin, som är en infrastruktur för reglering och spridning av geografisk data i Sverige (Geodatastrategin, u.å.).

Mot bakgrund av den stora tillgången på programvaror och data är de tekniska svårigheterna begränsade till användningen av GIS. Sådana svårigheter kan dock avhjälpas i undervisningen. Ratinen och Keinonen (2011) påvisar att handledning och grupparbete underlättar för elever, och Andersland (2011) påvisar att elever i årskurserna 7-9 behärskar relativt avancerade GIS under handledning.

\section{Möjligheter och svårigheter i lärarutbildningen}

Bednarz och Audet (2007) genomförde en övergripande studie av dels vilken status GIS har i amerikanska lärarutbildningar, dels hur GIS introduceras i dessa utbildningar. Även om både arbetande och blivande lärare behöver utbildas i GIS, så fokuserar studien på lärarstudenter. Bednarz och Audet antar att det är effektivare att börja utbilda lärarstudenter då de har mer tid till förfogande jämfört med arbetande lärare. Kvantitativa data samlades in genom stora utskick av frågeformulär till administrativa chefer på olika lärosäten och kvalitativa data samlades in genom intervjuer av lärare med ansvar för GIS-undervisningen. Resultaten visar på följande:

- Endast ett fătal lärosäten introducerar lärarstudenter till GIS.

- Lärarstudenter får ofta en ytlig introduktion till GIS.

- Ofta är målet med introduktionen att lärarstudenter ska bli medvetna om att tekniken finns, 
snarare än att de ska utveckla kunskaper och färdigheter.

- Ofta är det svårt att inkludera nytt material i redan pressade kursscheman.

- Många upplever att GIS har låg prioritet ute i skolorna och att man inte är medveten om vilken potential GIS har som tekniskt hjälpmedel i skolundervisningen.

- Det finns inget föredömligt exempel på hur GIS ska implementeras i lärarutbildningen.

Bednarz och Audet drar slutsatsen att få nyutexaminerade lärare har tillräckliga kunskaper för att uppfylla den nationella standard som redan finns. Då det är lärarutbildningars ansvar att förändra detta föreslår de användning av strategier för implementering av GIS och att geografilärare arbetar aktivt tillsammans med sina kollegor med denna implementering.

Studien aktualiserar administrativa och utbildningsmässiga problem förknippade med introduktion och utveckling av GIS i lärarutbildningen. Våra erfarenheter från den svenska lärarutbildningen bekräftar att GIS behandlas alltför ytligt och att lärarstudenters kunskaper därför är otillräckliga för att uppfylla skolans styrdokument. Därför är det viktigt med nya strategier för att implementera innehållet i styrdokumenten.

Ratinen och Keinonen (2011) undersökte (1) vilken kännedom finska lärarstudenter har om Google Earth, (2) i vilken utsträckning Google Earth kan användas som ett effektivt didaktiskt verktyg för att främja studenters geologiska och geografiska kunskaper och tänkande samt (3) hur studenter själva skulle vilja utveckla en kursmodul om GIS. Tio blivande gymnasielärare fick genomföra en problemorienterad kursmodul om Koli nationalpark och under tiden samlades kvalitativa data in genom observationer och intervjuer. Resultaten visar på att lärarstudenternas kännedom om Google Earth inte var särskilt stor och att denna behöver utvecklas för att de ska kunna använda programmet som ett effektivt redskap i sin framtida skolundervisning. Trots detta påvisar resultaten att det är möjligt att studera många olika geografiska fenomen med Google Earth och att detta främjar den geologiska och geografiska kunskapsutvecklingen. Studien visar också på en del svårigheter med användningen av GIS. Studenterna ansåg att det är viktigt med tydliga instruktioner i studentcentrerade uppgifter och betonade lärarens roll som handledare. Ratinen och Keinonen påpekar också att samarbete och grupparbete bör vara integrerade delar i denna typ av undervisning, på grund av de tekniska och innehållsmässiga svårigheterna med att använda och tillämpa GIS.

Jämfört med Bednarz och Audet (2007) undersöker denna studie lärarstudenters GIS-kunskaper på ett direktare sätt. Resultaten påvisar att kunskaperna inte räcker för deras framtida skolundervisning men att studier med Google Earth främjar deras kunskapsutveckling. Viktiga förutsättningar för detta är dock att studenter får handledning och att de arbetar aktivt i grupp. Vi har liknande erfarenheter från undervisning av blivande geografilärare för årskurserna 7-9.

Hauselt och Helzer (2012) utvecklade nya kursplaner för blivande grund- och gymnasielärare på California State University, mot bakgrund av en tidigare kritisk kursvärdering och att GIS är någonting nytt i utbildningen. Dessa kursplaner innehåller två GIS-delar: en där studenter lär sig mer om själva GIS-tekniken och en där de lär sig mer om GIS-tillämpningar. Enligt de nya kursvärderingarna anser $92 \%$ av studenterna att deras geografiska faktakunskaper har ökat avsevärt och $85 \%$ att deras färdigheter och problemlösningsförmåga har förbättrats avsevärt. Utöver detta introducerades ett utbytesprojekt mellan universitetet och en grundskola där studenterna fick planera och genomföra ett GIS-projekt tillsammans med lärare och elever i årskurs 4. Eleverna samlade in fältdata i sin närmiljö med GPS (Global Positioning System) och fotografering. Insamlad fältdata användes sedan för att, med hjälp av lärarstudenterna, framställa en karta som återspeglade elevernas syn på sin närmiljö. Resultatet av detta utbyte var genomgående positivt för lärarstudenterna, lärarna och eleverna: lärarstudenterna fick prova på att arbeta ute i verksamheten, lärarna fick tillgång till värdefullt undervisningsmaterial och eleverna fick prova på att arbeta med aktiva undervisningsformer. 
Precis som Ratinen och Keinonen (2011) undersöker denna studie lärarstudenters utveckling av GIS-kunskaper men även studenters omsättning av dessa kunskaper i skolundervisning. Genom att studera GIS-teknik och tillämpningar utvecklar studenter nya kunskaper och färdigheter med direkt relevans för aktivt lärande i skolan.

\section{Möjligheter och svårigheter i skolundervisningen}

Patterson (2007) utvecklade en lektionsplanering för årskurs 7 i Syd-Carolina för att demonstrera nyttan med att använda Google Earth i undervisningen. Lektionsplaneringen inkluderar inte bara Google Earths inbyggda flyg- och satellitbilder utan även KML- eller KMZ-filer med innehåll av olika typer av kompletterande information såsom digitaliserade beskrivningar av geografiska fenomen, fotografier, filmer och textinformation. Planeringen syftar till att stärka elevers faktakunskaper, förståelse och färdigheter samt olika förmågor som att tillämpa information för att lösa problem, analysera material och utvärdera olika lösningar. Avsikten är också att Google Earth ska hjälpa elever att utveckla sina kunskaper om följande: världen ur ett rumsligt perspektiv, platser och regioner, fysikaliska och biologiska processer, mänskliga processer, miljö och samhälle samt hur man kan tillämpa geografi i olika sammanhang. Även om Patterson anser att Google Earth främjar ett aktivt, forskningsbaserat och ämnesövergripande lärande, så pekar han på ett antal svårigheter med denna typ av teknikanvändning: Lärare behöver tillräckligt med tid och resurser för fortbildning och utveckling av undervisningsmaterial. En annan svårighet med tekniken är att elever lär sig om rumsliga processer och implikationer utan att förstå att det egentligen är geografi de lär sig mer om. Patterson påpekar också att Google Earth är begränsat vad gäller geografisk analys då det inte är ett äkta GIS. Slutligen betonar han att det är viktigt med ytterligare forskning för att fastställa nyttan med att använda Google Earth i undervisningen.

Denna studie bekräftar Ratinen och Keinonens (2011) resultat genom att påvisa att skolundervisning med Google Earth främjar ett aktivt, forskningsbaserat och ämnesövergripande lärande samtidigt som programvaran är aningen begränsad för utvecklad geografisk analys. För att undervisa på detta sätt krävs det tid och resurser för fortbildning av lärare och kursutveckling.

Andersland (2011) undersökte om GIS är ett lämpligt verktyg att använda i grundskolans geografiundervisning. Han utvecklade metodologiska redskap för GIS-undervisning i årskurs 8 som han sedan använde i en kvalitativ fallstudie. Övningsmaterialet var skrivet för den desktop-baserade programvaran ArcView med fokus på att eleverna skulle lära sig mer geografi med GIS snarare än att de skulle lära sig mer om själva GIS-tekniken. Eleverna genomförde sedan ett projektarbete där de skulle leka-och-lära om sin egen kommun med fokus på den framtida markanvändningen i skolans närområde. Datainsamlingen bestod av elevloggar, videoupptagningar, intervjuer och deltagande observation. Resultaten visar på att högstadieeleverna med framgång kan hantera ett desktop-baserat GIS i en lärandeprocess. Andersland poängterar den dubbla vinsten med GIS i undervisningen, dels att GIS innebär att arbeta med IKT, dels att GIS öppnar upp för arbete med konstruktivistiska, aktiva och problembaserade undervisningsformer. Det aktiva och problembaserade arbetssättet innebär bland annat insamling av fältdata samt bearbetning, analys och presentation av data. Han påpekar dock komplexiteten i att använda GIS i undervisningen som bottnar i lärares intresse samt tekniska, ekonomiska, pedagogiska, sociala och kulturella faktorer.

Jämfört med Patterson (2007) undersöker denna studie undervisning med ett äkta GIS för att främja ett aktivt och problembaserat lärande om geografi. Resultaten påvisar att elever kan hantera en mer avancerad programvara än Google Earth men att sådan undervisning ställer krav på bland annat lärares intresse och pedagogiska förmåga.

Favier och van der Schee (2012) genomförde en Educational Design Research-studie (EDR) tillsammans med nio gymnasielärare. Baserad på konstruktivistisk teori samt kooperativt och forskningsbaserat lärande syftade studien till att undersöka egenskaperna hos en optimal design för 
GIS-baserade geografiska projektarbeten. EDR-studien följde progressiva cykler av design, testning och utvärdering. De 375 elever som ingick i studien var mellan 15 och 17 år gamla. De kvalitativa data som samlades in under testen bestod av filmer av lektioner och elevpresentationer, fältanteckningar, intervjuer samt elevernas projektplaner och rapporter. Resultaten av studien består av ett antal principer för design och genomförande av GIS-baserade geografiska projektarbeten. Dessa principer användes senare av Environmental Systems Research Institute (ESRI) för utveckling av ett webbaserat GIS, för undervisning på gymnasienivå. Även om GIS främjar forskningsbaserat lärande betonar Favier och van der Schee att det inte räcker med programvaror, uppgifter och handledning för att uppnå bra resultat. Utöver stora handledningsinsatser krävs det förberedande uppgifter och efterföljande värderingar. Handledningen bör också bestå av en dialog mellan lärare och elever för att eleverna ska lära sig att strukturera, korrigera och expandera det geografiska tänkandet.

Denna omfattande designstudie på gymnasienivå bekräftar Pattersons (2007) och Anderslands (2011) resultat genom att användning av GIS främjar ett kooperativt och forskningsbaserat lärande. Samtidigt ställer detta stora krav på förberedelser, handledning och uppföljning. De identifierade designprinciperna användes senare för utveckling av ett webbaserat GIS som är ett bra sätt att tillgängliggöra ett skräddarsytt system för skolundervisning.

\section{Diskussion}

Mot bakgrund av ovanstående genomgång antar vi ett lösningsorienterat perspektiv och diskuterar följande teman:

- Tekniska lösningar

- Undervisning i enlighet med skolans styrdokument

- Undervisning för att främja studenters och elevers lärande

Då både lärarutbildningen och skolundervisningen utgår från skolans styrdokument och därför är intimt sammankopplade diskuterar vi dessa gemensamt under varje tema.

\section{Tekniska lösningar}

I Sverige är de tekniska hindren relativt få, då universitet/högskolor och skolor tillhandahåller datorer och både programvaror och data finns tillgängliga på internet. Dessutom kan universitet/högskolor och skolor få tillgång till Lantmäteriets dataproduktion (Geodatastrategin, u.å.). Det kan förvisso innebära vissa problem att avgöra vilka programvaror som man vill använda i skolundervisningen. Sammantaget påvisar genomgångna studier att internet- och webbaserade samt äkta GIS framgångsrikt kan användas i lärarutbildningen och skolundervisningen (Andersland, 2011; Pattersons, 2007; Ratinen och Keinonen, 2011). Patterson (2007) påpekar att internetbaserade Google Earth är aningen begränsad genom att inte vara ett äkta GIS som innehåller verktyg för avancerad geografisk analys. Andersland (2011) använde ett äkta GIS i sin studie även om denna programversion var modifierad för skolundervisning. Våra erfarenheter av lärarutbildningen och skolans geografiundervisning är att internet- och webbaserade GIS är lämpliga för alla nivåer medan äkta GIS kan introduceras i gymnasieskolan. Skolverket (2016a) skriver att vi är inne i en spännande utvecklingsfas där enklare programvaror som Google Earth och webbaserade GIS kombineras med GPS-funktioner i smarta mobiler. Webbaserade GIS är något som kan vara en stor tillgång i undervisningen, då dessa inte kräver någon installation av programvaror, är enkla att använda och kan skräddarsys för olika utbildningsnivåer. Det är dock en stor fördel om skollärare behärskar GIS på olika nivåer, vilket innebär att de bör få med sig tillräckliga kunskaper från lärarutbildningen. 


\section{Undervisning i enlighet med skolans styrdokument}

Trots att GIS bidrar med goda förutsättningar för att utveckla geografiundervisning i enlighet med tillämplig pedagogik påvisar Bednarz och Audets (2007) studie att endast ett fåtal amerikanska lärosäten introducerar lärarstudenter till GIS. Det är intressant att notera de stora likheterna med situationen i Sverige. Lärare som har studerat enligt de gamla läroplanerna för grund- och gymnasieskolan saknar ofta GIS-kunskaper, och enligt Skolverket (2016a) har endast cirka femton svenska gymnasieskolor genomfört den särskilda programkursen i GIS. Ansvaret att implementera innehållet i styrdokumenten ställer krav på lärarutbildare, lärarstudenter, skollärare och elever. Med utgångspunkt i styrdokumenten måste lärarutbildare ha tillräckliga kunskaper för att utbilda lärarstudenter i GIS och relaterad ämnesdidaktik. Patterson (2007) problematiserar utbildningen av lärare ytterligare med att det är tid- och resurskrävande att förändra kursplaner och att utveckla nytt undervisningsmaterial. Om det inte finns ekonomiska resurser till att finansiera kursutvecklingstid, så kan det dröja innan lärarutbildningen och skolundervisningen helt och fullt implementerar skolans styrdokument (Skolverket, 2016b). Lärarutbildningen har ett ansvar att uppfylla styrdokumenten men att göra detta kräver en hel del. Å andra sidan är det en rimlig tolkning av ämnes- och kursplanerna för både årskurserna 7-9 och gymnasiet att fokus bör ligga på att undervisa med GIS om olika geografiska innehåll, och för att göra detta kommer man ganska långt med internet- och webbaserade GIS. Dessa programvaror är enkla att använda samtidigt som de kan anpassas efter olika årskurser och kunskapskrav. Genom att börja här kan lärarutbildare och skollärare i lämplig takt utveckla sina kunskaper om GIS-tekniken för att i förlängningen utnyttja dess fulla potential i undervisningen (Bednarz \& Audet, 2007).

\section{Undervisning för att främja studenters och elevers lärande}

Genomgångna studier påvisar att GIS öppnar upp för geografiundervisning, både i lärarutbildningen och skolundervisningen, som baseras på aktivt, forskningsbaserat, kooperativt och problembaserat lärande, och som främjar lärande om komplexa ämnesövergripande problemområden (Andersland, 2011; Favier \& van der Schee, 2012; Hauselt \& Helzer, 2012; Patterson, 2007; Ratinen \& Keinonen, 2011). Detta skulle kunna förändra skolans undervisning från att fokusera på namngeografi till att bli mer problemorienterad (Molin, 2006; Molin och Örbring, 2017) och på detta sätt öka elevers möjligheter att uppnå de förmågor som styrdokumenten föreskriver (Carlgren 2011; Svanelid, 2014). Detta förutsätter dock ett stort engagemang hos lärarutbildare och skollärare vad gäller utveckling av undervisningsmaterial och handledning av projekt (Andersland, 2011; Ratinen \& Keinonen, 2011). Lärares förmågor att skapa ett öppet klimat och föra en dialog med studenter och elever samt att ge formativ feedback är avgörande för positiva resultat (Biggs \& Tang, 2007; Favier \& van der Schee, 2012). De kunskaper och förmågor som nyutexaminerade lärare tar med sig ut i skolan ger avtryck på deras undervisning.

Detta ställer krav på att lärarutbildare och skollärare kombinerar teknologisk kunskap om GIS med pedagogisk ämneskunskap (Shulman, 1986) för att uppnå den teknologiska pedagogiska ämneskunskap (Mishra \& Koehler, 2006) som behövs för att kunna undervisa både om GIS och med GIS (Favier \& van der Schee, 2012). Med gedigen teknologisk pedagogisk ämneskunskap är lärare väl rustade för att tillämpa de mest användbara representationsformerna i olika lärandesituationer. Genom att variera undervisningen med olika exempel, analogier, förklaringar, illustrationer och demonstrationer når lärare fram till elever med olika förkunskaper och perspektiv. De genomgångna studierna om undervisning med GIS påvisar goda resultat (Andersland, 2011; Hauselt \& Helzer, 2012; Patterson, 2007; Ratinen \& Keinonen, 2011), och bara en sådan enkel sak som att låta elever kombinera och variera grafik med satellit- och flygbilder i Google Earth underlättar lärande om exempelvis tektoniska plattor och deras rörelser (Figur 1). Dessutom har geografi och GIS stor potential att samordna ämnesövergripande skolundervisning om komplexa problemområden. Detta utesluter givetvis inte undervisning om GIS, vilken är en förutsättning för att på bästa sätt kunna använda sig av GIS: Anta att elever har varit på exkursion och använt GPS-funktioner i sina mobiler för att koordinatsätta information om ett antal platser. Kunskaper om hur GIS hanterar lägesbunden data underlättar elevers 
förståelse av hur de kan importera sina koordinater och insamlad information till exempelvis Google Earth för att visualisera detta mot en bakgrund av satellit- eller flygbilder.

\section{Slutsatser och rekommendationer}

Sammanfattningsvis är förutsättningarna goda för GIS-baserad undervisning i både lärarutbildningen och skolundervisningen. De tekniska hindren är få med god tillgång på datorer, programvaror och data. Dock behöver en del svårigheter övervinnas, exempelvis svårigheter relaterade till tid, resurser, utbildning, fortbildning och utveckling av undervisningsmaterial. Lärarutbildare och skollärare behöver utveckla teknologisk pedagogisk ämneskunskap för att undervisa om och med GIS och utnyttja den potential som GIS har för att främja aktivt, forskningsbaserat, kooperativt och problembaserat lärande om komplexa ämnesövergripande problemområden. Sådant lärande skulle främja elevers möjligheter att uppnå de förmågor som styrdokumenten föreskriver. Mot bakgrund av ovanstående diskussion kan några gemensamma rekommendationer för lärarutbildningen och skolundervisningen identifieras:

- Inledningsvis bör möjligheterna med GIS i form av exempelvis analys och visualisering komma lärarutbildare och skollärare till del. Detta skulle kunna åstadkommas genom inspirerande och fördjupande föreläsningar och workshoppar där möjligheter med GIS tydliggörs.

- Utifrån dessa föreläsningar kan möjliga resurser för och behov av fortbildning identifieras. Inledningsvis kan det räcka med mindre tid och resurser för lärarutbildare och skollärare att komma igång med enklare internet- och webbaserade GIS för att sedan i lämplig takt utveckla sina kunskaper om och med GIS.

- Fortbildningen i GIS bör sedan följas upp med didaktiskt orienterad fortbildning i form av föreläsningar och workshoppar där kunskapskrav i läro-, ämnes- och kursplanerna för årskurserna 7-9 och gymnasiet identifieras, liksom progressioner i lärandet mellan årskurserna och lämpliga didaktiska upplägg.

- Genom forskning och samverkan mellan universitet/högskolor och skolor kan inspirerande undervisningsmaterial för aktivt, forskningsbaserat, kooperativt och problembaserat lärande med GIS utvecklas. Genom att lärarstudenter och elever arbetar aktivt med GIS lär de sig mer och mer om GIS.

- I förlängningen kan undervisningsmaterial för lärande om komplexa ämnesövergripande problemområden utvecklas. Genom att arbeta ämnesövergripande får lärare hjälp av varandra, och studenter och elever lär sig integrera kunskap. En annan synergieffekt är att man sparar undervisningstid genom att undervisning om och med GIS på olika sätt kan utgöra måluppfyllelse för flera kurser och ämnen samtidigt.

\section{REFERENSER}

Andersland, S. (2011). GIS i geografifaget på ungdomstrinnet. Fagdidaktiske perspektiv på å lære om og med GIS. Trondheim: Geografisk Institutt NTNU. http://hdl.handle.net/11250/265347

Baker, T. R., \& Bednarz, S. W. (2003). Lessons learned from reviewing research in GIS education. Journal of geography, 102(6), 231-233. http://dx.doi.org/10.1080/00221340308978554

Bednarz, S. W., \& Audet, R. H. (1999). The status of GIS technology in teacher preparation programs. Journal of Geography, 98(2), 60-67. http://dx.doi.org/10.1080/00221349908978861

Biggs, J. B., \& Collis, K. F. (1982). Evaluating the quality of learning - the SOLO taxonomy. New York: Academic Press.

Biggs, J. B., \& Tang, C. S. (2007). Teaching for quality learning at university. New York: McGrawHill.

Carlgren, I. (2011). Kunnande - kunskap - kunnighet. In L. Lindström, V. Lindberg, \& A. Pettersson (Eds.), Pedagogisk bedömning: att dokumentera, bedöma och utveckla kunskap (pp. 43-58). Stockholm: Stockholms Universitets förlag. 
Demirci, A. (2009). How do teachers approach new technologies: Geography teachers' attitudes towards Geographic Information Systems (GIS). European Journal of Educational Studies, 1(1), 43-53. https://www.researchgate.net/publication/228343724

Favier, T. T., \& van der Schee, J. A. (2012). Exploring the characteristics of an optimal design for inquiry-based geography education with Geographic Information Systems. Computers \& Education, 58(1), 666-677. http://dx.doi.org/10.1016/j.compedu.2011.09.007

Geodatastrategin (u.å.). Geodatastrategin. Retrieved April 22, 2018, from https://www.geodata.se/ styrande/nationell-geodatastrategi/

Goodell, L. (2016). Using Google Earth to explore plate tectonics. Retrieved November 5, 2016, from the Science Education Resource Center at Carleton College (SERC): http://serc.carleton.edu/ NAGTWorkshops/teaching_methods/google_earth/examples/49004.html

Google Earth (2016). Northern hemisphere centered on Europe $54^{\circ} 17^{\prime} 50.47^{\prime \prime N}, 18^{\circ}$ o'0.46”O. Satellite data. Retrieved November 5, 2016, from http://www.google.com/earth/index.html

Harrie, L. (red.) (2012). Geografisk informationsbehandling: teori, metoder och tillämpningar. Lund: Studentlitteratur AB.

Hauselt, P., \& Helzer, J. (2012). Integration of geospatial science in teacher education. Journal of Geography, 111(5), 163-172. http://dx.doi.org/10.1080/00221341.2011.638722

Johansson, T. P. (2012). Finland: Diffusion of GIS in schools from local innovations to the implementation of a national curriculum. In A. J. Milson, A. Demirci, \& J. Kerski (Eds.), International perspectives on teaching and learning with GIS in secondary schools (pp. 89-96). Springer Netherlands.

Kerski, J. J. (2003). The implementation and effectiveness of geographic information systems technology and methods in secondary education. Journal of Geography, 102(3), 128-137. http:// dx.doi.org/10.1080/00221340308978534

Lam, C.-C., Lai, E., \& Wong, J. (2009). Implementation of geographic information system (GIS) in secondary geography curriculum in Hong Kong: Current situations and future directions. International Research in Geographical and Environmental Education, 18(1), 57-74. http://dx.doi. org/10.1080/10382040802591555

McKeachie, W. J., \& Svinicki, M. (2006). Teaching tips: Strategies, research, and theory for college and university teachers. Boston: Houghton Mifflin Company.

Marton, F., \& Säljö, R. (1976). On qualitative differences in learning I - Outcome and process. British Journal of Educational Psychology, 46(1), 4-11. http://dx.doi.org/10.1111/j.2044-8279.1976. tbo2980.x

Mishra, P., \& Koehler, M. J. (2006). Technological pedagogical content knowledge: A framework for teacher knowledge. Teachers College Record, 108(6), 1017-1054.

Molin, L. (2006). Rum, frirum och moral - En studie av skolgeografins innehållsval. Ph.D. thesis. Uppsala: Uppsala universitet.

Molin, L., \& Örbring, D. (2017). Past didactic influence and present efforts to create learning progressions. In O. M. Solari, M. Solem, \& R. Boehm (Eds.), Learning progressions in geography education (pp. 55-74). Springer International Publishing.

Patterson, T. C. (2007). Google Earth as a (not just) geography education tool. Journal of Geography, 106(4), 145-152. http://dx.doi.org/10.1080/00221340701678032

Ramsden, P. (1992). Learning to teach in higher education. London: Routledge.

Ratinen, I., \& Keinonen, T. (2011). Student-teachers' use of Google Earth in problem-based geology learning. International Research in Geographical and Environmental Education. 2O(4), 345358. http://dx.doi.org/10.1080/10382046.2011.619811

Schubert, J. C., \& Uphues, R. (2009). Learning with geoinformation in German schools: Systematic integration with a GIS competency model. International Research in Geographical and Environmental Education. 18(4), 275-286. http://dx.doi.org/10.1080/10382040903251141

Shulman, L. S. (1986). Those who understand: Knowledge growth in teaching. Educational Researcher, 15(2), 4-14. 
Skolverket (u.å.a). Kursplan - Geografi. Retrieved April 22, 2018, from http://www.skolverket.se/ laroplaner-amnen-och-kurser/grundskoleutbildning/grundskola/geografi

Skolverket (u.å.b). Ämne - Geografi. Retrieved April 22, 2018, from http://www.skolverket.se/laroplaner-amnen-och-kurser/gymnasieutbildning/gymnasieskola/geo?tos=gy\&subjectCode=GEO \&lang $=\mathrm{SV}$

Skolverket (2016a). GIS en möjlighet och utmaning. Retrieved April 22, 2018, from http://www. skolverket.se/skolutveckling/forskning/amnen-omraden/so-amnen/geografi/undervisning/ gis-i-geografiundervisningen-1.197433

Skolverket (2016b). Läroplaner, ämnesplaner och kursplaner. Retrieved April 22, 2018, from http:// www.skolverket.se/laroplaner-amnen-och-kurser

Svanelid, G. (2014). De fem förmågorna i teori och praktik - Boken om The Big 5. Lund: Studentlitteratur AB.

Wechsler, S. P., \& Pitts, L. A. (2004). GIS in high school integrates geography with technology: A case study. The California Geographer, 44, 38-54. http://hdl.handle.net/10211.2/2761

Yong Yap, L., Tan, G. C. I., Zhu, X., \& Wettasinghe, M. C. (2008). An Assessment of the use of geographical information systems (GIS) in teaching geography in Singapore schools. Journal of Geography, 107(2), 52-60. http://dx.doi.org/10.1080/00221340802202047 